\title{
Comparative Evaluation of Different Salt-Tolerant Plant Growth-Promoting Bacterial Isolates in Mitigating the Induced Adverse Effect of Salinity in Pisum sativum
}

\author{
Anmol Gupta ${ }^{1(D)}$, Smita Rai ${ }^{1}$ (D), Ambreen Bano ${ }^{1(D)}$, Afreen Khanam ${ }^{2}$, Swati Sharma ${ }^{2 *}$, D , Neelam \\ Pathak $^{3, * \text { (D) }}$ \\ 1 IIRC-3, Plant-Microbe Interaction and Molecular Immunology Laboratory, Department of Biosciences, Faculty of \\ Sciences, Integral University, Lucknow, UP, India; anmolgupta632@gmail.com (A.G.); shiblyrai@gmail.com (S.R.); \\ ambreenbano2408@gmail.com (A.B.); sw_sh@rediffmail.com (S.S.); \\ 2 IIRC-1, Laboratory of Glycation Biology and Metabolic Disorder, Department of Biosciences, Faculty of Sciences, \\ Integral University; affie213@gmail.com (A.K.); \\ 3 Department of Biochemistry, Dr. Rammanohar Lohia Avadh University, Ayodhya, UP, India; \\ pathak.neelam007@gmail.com (N.P.); \\ * Correspondence: pathak.neelam007@gmail.com (N.P.); sw_sh@ rediffmail.com (S.S.) \\ Scopus Author ID 56548366100 (N.P.); 57198535273 (S.S.)
}

Received: 7.01.2021; Revised: 30.01.2021; Accepted: 1.02.2021; Published: 7.02.2021

\begin{abstract}
Due to climate change, salinity has become a limiting factor for many leguminous crops. Therefore, we have explored the comparative study of salt-tolerant plant growth-promoting rhizobacteria (PGPR) for the promotion of plant growth. These PGPR (Bacillus subtilis RhStr_71, Bacillus safensis RhStr_223, and Bacillus cereus RhStr_JH5) were in vitro screened for plant growthpromoting (PGP) traits such as IAA, P-solubilization, siderophore, and ammonia production. They were further selected to evaluate the maximum $\mathrm{NaCl}$ tolerant level (MTL). Selected salt-tolerant PGP bacteria were further characterized to evaluate their PGP activity on seedlings of Pisum sativum under $1 \% \mathrm{NaCl}$ stress. They were further selected to perform the greenhouse experiments under $1 \% \mathrm{NaCl}$ stress to compare these isolates on morphological (like plant height and weight) and biochemical parameters(such as carbohydrate, reducing sugar, protein, phenol, flavonoids, chlorophylls, and carotenoids). In a pot experiment, $\mathrm{NaCl}$ significantly reduced the plant growth parameters compared to un-inoculated and inoculated. Additional analysis also had shown that these strains also enhanced the antioxidant enzymes, thereby preventing oxidative damage caused due to reactive oxygen species (ROS). The result revealed that these salt-tolerant PGP bacteria exert their beneficial effects on plant growth and play a necessary role in attenuating the salinity stress in agriculture.
\end{abstract}

Keywords: PGPR; plant growth-promoting (PGP) traits; $\mathrm{NaCl}$; salt tolerance; antioxidants enzymes; Pisum sativum.

(C) 2021 by the authors. This article is an open-access article distributed under the terms and conditions of the Creative Commons Attribution (CC BY) license (https://creativecommons.org/licenses/by/4.0/).

\section{Introduction}

Worldwide, salinity led to the decline of crop production and plant growth in many cultivated areas [1], leading to a $65 \%$ loss of crop yield [2]. In India, salinity affects a complete of 9.38 Mha land, while specifically, the Gujarat state has a major share of the saline-affected vicinity of approximately 2.23 Mha [3]. Amongst crop vegetation, cereals and legumes are the foremost sensitives to salt. Even $100 \mathrm{mM}$ of salinity in legumes is sufficient to inhibit the nodule formation and eventually the nitrogen fixation [4]. Pisum sativum is an important leguminous crop sensitive to salinity, and because of its salinity, it is widely used as an indicator for 
research analysis [5]. Salinity stress is well-defined as the existence of excess amounts of salts (soluble) in the soil, which hinders the growth and functioning of the Pea plant [6]. During the first step of salinity stress, the potential of rootage to soak up water decreases, and therefore the water loss from the leaves increases. It is due to the accumulation of high salt caused by osmotic pressure [7]. This osmotic stress causes diverse physiological adjustments, including nutrient imbalance, interruption of membranes, impairing the capability to detoxify the reactive oxygen species (ROS), fluctuations in antioxidant enzymes, and reduction in stomatal aperture, and minimize the photosynthetic activity [8]. Beneath high salinity, the elevated sodium $\left(\mathrm{Na}^{+}\right)$ and chloride $\left(\mathrm{Cl}^{-}\right)$concentrations result in an ionic imbalance in plant tissues, which ends up in decreasing nutrient uptake [9].

Determination of seeds' germination ability under saline situations should appear as the beneficial and simple parameter for selecting salt-resistant populations [10]. Furthermore, salinity stress is broadly said to negatively affect seed germination, plant growth and development, nutrient uptake, yield, and crop productivity [11, 12]. It is due to the statement that germination typically takes place in surface soils, which gather soluble salts due to evaporation and capillary push of water content in the soil, thereby decreasing numerous factors along with phytohormones and ROS signaling [13]. It has been documented that the photosynthetic pigment concentrations were drastically reduced in salt-stressed plants [14]. A reduction in the chlorophyll contents signifies that the plant is experiencing abiotic stress [15], and negatively influences the photosynthetic rate. Lowering of photosynthetic rates in crops under abiotic saline stress are correlated with the extreme accumulation of $\mathrm{Na}^{+}$and $\mathrm{Cl}^{-}$ concentrations and reduced water potential in the chloroplasts and chlorophyll, which immediately impact plant health [9]. The deleterious effects of salinity on photosynthesis and protein synthesis have also been notified by many other researchers [16, 17]. The seedlings subjected to low-salt stress confirmed a remarkable decline in superoxide dismutase (SOD) and catalase (CAT) activity in comparison to non-stressed control groups [18].

The plant's defense mechanism to the osmotic component of salt stress includes the accumulation of osmoprotective materials, including proline, sucrose, and mannitol [19]. Proline, a low molecular weight (m.w.) osmoprotectant is a biochemical indicator of osmotic adjustment in plant cells and organs [20]. One of the foremost devastating aspects of oxidative stress is lipid peroxidation, which disrupts the cellular-membrane structure and ultimately provokes necrobiosis. To enhance the plant salinity tolerance, several tactics towards sustainable development of agriculture become accomplished. As innovative technologies, RDT (Recombinant DNA Technology) and plant breeding are often accustomed to increase salt-tolerant varieties efficiently but are very time-consuming. In agriculture, microbial technology is one of the technologies wished nowadays and within the future for sustainable crop productiveness [21]. Seeing that Hilter explained on the rhizosphere concept in 1904 that plant growth-promoting rhizobacteria (PGPR) are used as bio-agents for promoting plant health to conquer salt stress management [22]. Its utilization is one of the most alternative, promising, and economic approaches to revamp crop production in saline stress soils [23, 24]. Bacillus and Pseudomonas species are the foremost extensively investigated rhizobacteria that facilitate plant health [21].

To our knowledge, no other studies are implemented before using these isolates that have been diagnosed for their salt tolerance property in Pea plants. Thus, this research mainly aimed towards estimating the potential impacts of these three salt-tolerant isolates on positive changes in various morphological parameters of growth, and biochemistry, including the 
carbohydrate, protein, reducing sugars, chlorophylls, phenols, flavonoids, and antioxidant defense system, in Pea plants grown under $\mathrm{NaCl}$ conditions.

\section{Materials and Methods}

\subsection{Bacterial strains.}

Bacillus sp. such as RhStr_71, RhStr_223, and RhStr_JH5, were previously isolated from rhizospheric soil from North India and was used throughout this study.

2.2. In vitro characterization of bacterial isolates for plant growth-promoting (PGP) traits and determination of maximum tolerance level (MTL).

The selected three strains were characterized for their PGP traits. IAA assay was done using L-tryptophan $/ \mathrm{mL}$ and Salkowski's reagent earlier described by [25]. Tri-calcium phosphate (TCP) solubilization quantitatively for phosphate solubilization in a liquid medium is also described [26]. Ammonia production was determined using Nessler's reagent with slight modifications as per Goswami's method [27]. Siderophore production was detected using the Chrome azurol S agar (CAS) medium described by [28].

The MTL level of the selected isolates toward salinity $(\mathrm{NaCl})$ stress was screened using nutrient broth (NB) with dissimilar levels of $\mathrm{NaCl}$ salt $(1,2$, and $3 \% \mathrm{NaCl}$ w/v) with varying time intervals at $600 \mathrm{~nm}[29]$.

\subsection{Evaluation of PGP activity of PGPR under $\mathrm{NaCl}$ stress condition in Pisum sativum.}

Based on in vitro plant growth-promoting assays, these bacterial isolates were further selected to evaluate their effect on Pea seed at the germination phase in the presence of different salinity levels. For Bacterial inoculum preparation, overnight grown bacterial cells having CFU $1 \times 108$ cells/ml were harvested by centrifugation (6000 rpm for 10 minutes) and were washed twice with $50 \mathrm{mM}$ phosphate saline buffer (PBS) and re-suspended thereof in 1:1 in distilled water $(\mathrm{d} / \mathrm{w})$ to maintain the uniform cell density of $1 \times 10^{8} \mathrm{CFU} \mathrm{ml}{ }^{-1}$. For plant trial assay, Pea seeds were then surface sterilized with $\mathrm{d} / \mathrm{w}$ followed by $0.1 \%$ of $\mathrm{HgCl}_{2}$. The seeds were bacterized by coating with the culture suspension of selected strains. The seeds were air-dried overnight in a Laminar Air Flow under sterile conditions to perform pot experiments.

\subsection{Seedlings parameters.}

The germinated seeds were measured once per day (simultaneously) until the end of the 10th day after seeding. The germination percentage (GP) was calculated according to theInternational Seed Testing Association (ISTA) method:

GP $=$ number of normally germinated seeds/total number of seeds sown $\times 100$

The germination index (GI) was calculated using the following formula:

$$
(\mathrm{GI})=\Sigma(\mathrm{Gt} / \mathrm{Tt}) \text {, }
$$

where, Gt is the number of seeds germinated on day $\mathrm{t}$, and $\mathrm{Tt}$ is the number of days [30].

Other growth parameters such as Mean germination time (MGT), total germination (TG)\%, coefficient of the velocity of germination (CVG), Germination rate index (GRI), and Vigour index were also measured [31]. 


\subsection{Greenhouse experiment.}

The tyndallized autoclaved soil was then filled, and seeds were then sown in sterile thermo coal pots $(5.95 \mathrm{~cm} \times 5.3 \mathrm{~cm} \times 4.2 \mathrm{~cm})$. There were five replicates of each treatment, such as control (normal) and bacteria-inoculated (RhStr_71, RhStr_223, RhStr_JH5) pots in normal and bacteria with salt amended soil. The salinity stress was artificially induced by adding $1 \% \mathrm{NaCl}$ to the soil. The pots were kept in greenhouse conditions and irrigated with distilled water when required. The plants were monitored regularly, and after 30 days of sowing, plants were harvested to examine the shoot and root length; fresh and dry weights. The harvested plants were further studied to determine the changes in biochemical parameters.

\subsection{Biochemical analysis.}

A 100mg of the fresh shoot were homogenized in $2 \mathrm{ml}$ of a $50 \mathrm{mM}$ ice-chilled phosphate buffer ( $\mathrm{pH}$ 8.0) in a cool mortar and pestle. The homogenate was further centrifuged at 12,000 ( $\mathrm{x} \mathrm{g}$ ) for 12 minutes at $4^{\circ} \mathrm{C}$. The supernatant was additionally used for enzymatic assays. Total sugar content was evaluated using the method of [32], and reducing sugars were estimated by following Somogy's method as modified by [33] taking glucose as a standard. The protein concentration was estimated as per the method given by [34] using bovine serum albumin (BSA) as a standard. The chlorophyll content of the leaves was estimated according to [35]. The proline content in the shoot was measured via reaction with ninhydrin [36]. It was estimated by equating with a standard curve of L-proline (Sigma-Aldrich, USA) standard. The total phenols in plant samples were determined by the Folin-Ciocalteu method given by [37] using gallic acid as a standard. The quantitative estimation was performed spectrophotometrically by the aluminum chloride method based on the formation of complex flavonoid- aluminum [38], taking quercetin as a standard.

\subsection{Antioxidant enzymes activity.}

The enzymatic activities of antioxidants such as Superoxide dismutase (SOD), catalase (CAT), Ascorbate peroxidase (APX), and Peroxidase (POX) were determined. SOD activity was estimated as per the method described by [39]. SOD activity was determined by [40] and the enzyme's ability to inhibit photochemical reduction of nitroblue tetrazolium (NBT) on blue formazan, followed by monitoring the absorbance of the reaction mixture at $560 \mathrm{~nm}$. The catalase activity was determined by observing the disappearance of $\mathrm{H}_{2} \mathrm{O}_{2}$ at $240 \mathrm{~nm}$ after adding enzyme extract to the reaction mixture [41] and was quantified by using the extinction coefficient $\left(3.99 \mathrm{~mm}^{-1} \mathrm{~cm}^{-1}\right)$. Peroxidase assay was determined by [42] and quantified using the extinction coefficient $\left(2.13 \mathrm{~mm}^{-1} \mathrm{~cm}^{-1}\right)$. POX activity was defined as $\mathrm{mmol} \mathrm{H}_{2} \mathrm{O}_{2}$ decomposed $\mathrm{ml}^{-1} \mathrm{~min}^{-1}$. APX activity of total shoot was estimated at $290 \mathrm{~nm}$ by the method described by [43]. The activity of ascorbate peroxidase was determined based on the reduction in absorbance at $290 \mathrm{~nm}$ (absorbance coefficient $2.8 \mathrm{mM}^{-1} \mathrm{~cm}^{-1}$ ) as ascorbate was oxidized. Lipid peroxidation is easily detected by quantifying the concentration of malonyl di-aldehyde (MDA), a byproduct of the process as per the method prescribed by [44].

\subsection{Statistical analysis.}

The experimental values are presented as the mean of three replicates. The results were expressed as mean, and error bars represent the standard deviation $( \pm \mathrm{SD})$ and the mean $( \pm \mathrm{SEM})$ standard error. Multiple comparisons were conducted using one-way ANOVA analysis, and 
data were compared using "Tukey's Multiple Comparison Test" performed by using GraphPad Prism (GraphPad In-Stat version 5.00, GraphPad Software, San Diego, CA, USA). Different letters in graphs indicate significant differences between treatments $(P<0.05)$, while the same values indicate the non-significant between the samples.

\section{Results and Discussion}

\subsection{PGP traits of bacterial strains.}

The selected bacterial strains were positive for PGP traits. Among them, bacterial isolates RhStr_71 (Bacillus subtilis) shows the highest activity towards PGP traits compared with other strains (Table 1).

Table 1. Characteristics of PGPR. RhStr_71 (Bacillus subtilis), RhStr_223R (Bacillus safensis), RhStr_JH5 (Bacillus cereus).

Test for salt-tolerant bacterial isolates

\begin{tabular}{|c|c|c|c|c|c|}
\hline \multirow{2}{*}{$\begin{array}{c}\text { Bacterial } \\
\text { strains }\end{array}$} & IAA (with tryptophan) & P-solubilization & \multirow{2}{*}{$\begin{array}{c}\text { Ammonia } \\
\text { production }\end{array}$} & \multirow{2}{*}{$\begin{array}{c}\text { Siderophore } \\
\text { production }(\%)\end{array}$} & \multirow{2}{*}{$\begin{array}{c}\text { NCBI gene } \\
\text { accession No. }\end{array}$} \\
\hline & $(\mu \mathrm{g} \mathrm{mL-1})$ & $(\mu \mathrm{g} / \mathrm{mL}-1)$ & & & \\
\hline RhStr_71 & $79.0 \pm 2.68$ & $84 \pm 3.1$ & + & $17.1 \pm 0.9$ & KT429585.1 \\
\hline RhStr_223R & $57.6 \pm 3.14$ & $72 \pm 2.2$ & + & $26.7 \pm 0.8$ & KT751329.1 \\
\hline RhStr_JH5 & $36.8 \pm 3.65$ & $60 \pm 1.7$ & + & $30.6 \pm 0.4$ & KT429594.1 \\
\hline
\end{tabular}

$(+)=$ Positive production; Indole acetic acid (IAA); Phosphate solubilization. Values are mean of three replicates \pm standard deviation $(\mathrm{SD})$.

\subsection{Determination of maximum tolerance level (MTL) of NaCl by PGP bacteria.}

The result shows that $2 \% \mathrm{NaCl}(\mathrm{w} / \mathrm{v})$ did not affect the bacterial count on the growth of Bacillus isolates, whereas on increasing the salt concentration, a decrease in OD value was obtained, resulting in the substantial inhibition of bacterial growth (Figure 1) and on inoculation of $3 \% \mathrm{NaCl}$ in $\mathrm{NB}$ some of the bacterial isolates inhibit the bacterial growth.

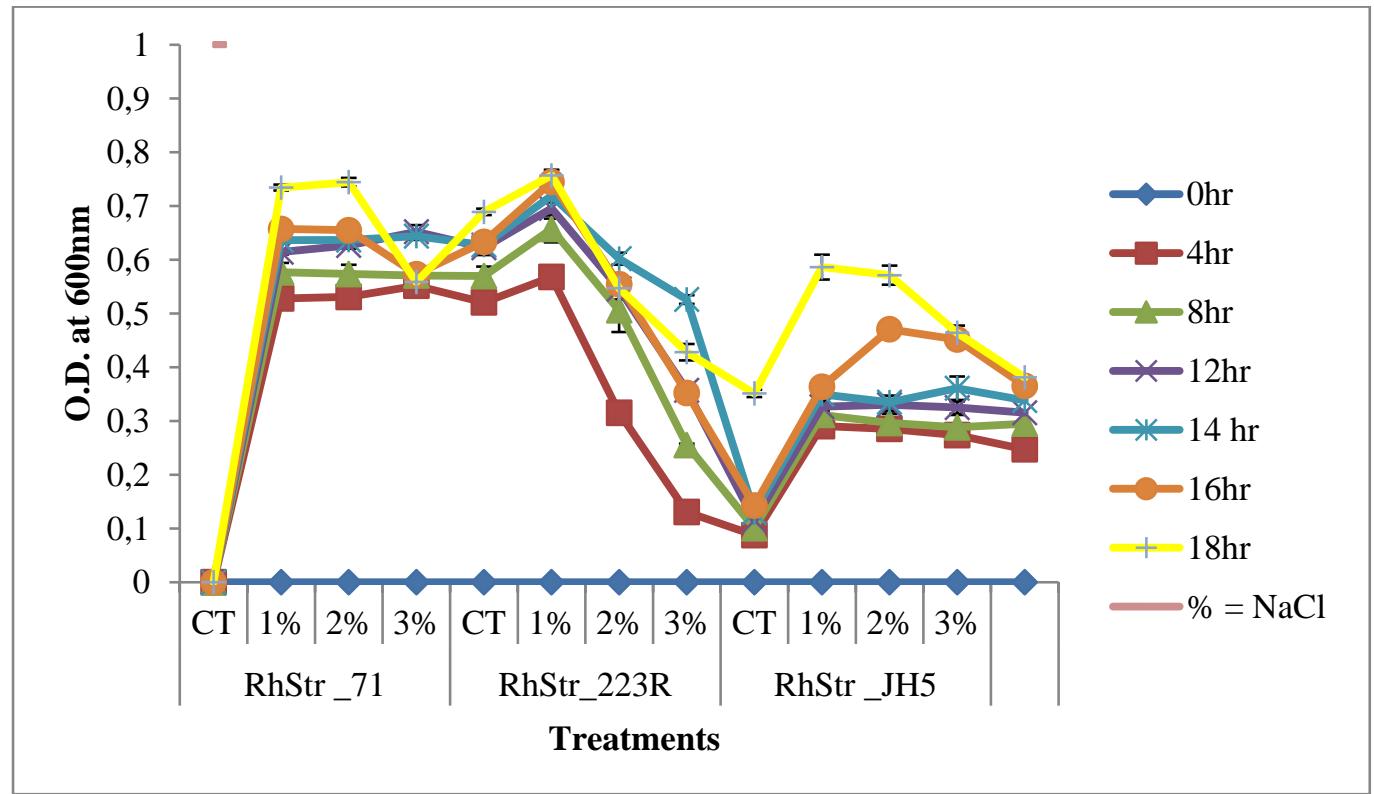

Figure 1. Growth curve analysis of bacterial strains (RhStr_71, RhStr_223R, RhStr_JH5) under different $\mathrm{NaCl}$ stress. CT: no salt inoculation; RhStr_71 (Bacillus subtilis), RhStr_223R (Bacillus safensis), RhStr_JH5 (Bacillus cereus): Bacterial treatments; 1\%, 2\%, and 3\%: different $\mathrm{NaCl}$ concentration. Values are the mean of three replicates. Error bars represent the standard deviation. 


\subsection{Seedlings parameters.}

Results showed that salinity had an adverse effect on seedling in Pisum sativum. The bacterial isolates further increase the plant growth-promoting attributes such as G\%, GI, MGT, TGP, CVG, GRI, and VI in Pea seedlings (Table 2) and RhStr_ 71 isolates in most significant among them.

Table 2. Effect of PGPRs on seedling parameters of Pea seedlings at $1 \% \mathrm{NaCl}$ concentration along with uninoculated (control). CT: Control without bacterial inoculation; RhStr_71, RhStr_223R, RhStr_JH5: Bacillus sp. isolates; $\mathrm{S} 1: 1 \% \mathrm{NaCl}$.

\begin{tabular}{|c|c|c|c|c|c|c|c|c|}
\hline S.No & Treatments & $\begin{array}{c}\text { Germination } \\
\%(\mathbf{G} \%)\end{array}$ & $\begin{array}{c}\text { Germination } \\
\text { index (GI) }\end{array}$ & $\begin{array}{c}\text { Mean } \\
\text { Germination } \\
\text { Time (MGT) }\end{array}$ & $\begin{array}{c}\text { Total } \\
\text { Germination } \\
\% \text { (TGP) }\end{array}$ & $\begin{array}{l}\text { Coefficient of } \\
\text { Velocity of } \\
\text { Germination } \\
\text { (CVG) }\end{array}$ & $\begin{array}{c}\text { Germina } \\
\text { tion Rate } \\
\text { Index } \\
\text { (GRI) } \\
\end{array}$ & $\begin{array}{c}\text { Vigour } \\
\text { Index } \\
\text { (VI) }\end{array}$ \\
\hline 1. & CT & 48 & 166.67 & 4.17 & 24 & 5.6 & 1593.26 & 1121.09 \\
\hline 2. & RhStr_71 & 104 & 366.67 & 9.01 & 60 & 24.78 & 3333.33 & 4809.04 \\
\hline 3. & RhStr_223R & 60 & 200.01 & 5.01 & 32 & 6.49 & 1829.37 & 3496.41 \\
\hline 4. & RhStr_JH5 & 53 & 191.67 & 4.21 & 28 & 8.28 & 1809.52 & 2248.81 \\
\hline 5. & $\mathrm{~S} 1$ & 19 & 83.33 & 1.67 & 16 & 1 & 543.65 & 370.29 \\
\hline 6. & RhStr_71+S1 & 59 & 233.33 & 5.37 & 44 & 9.88 & 1970.24 & 2655.58 \\
\hline 7. & RhStr_223R+S1 & 24 & 100.06 & 2.15 & 20 & 1.55 & 682.54 & 1324.57 \\
\hline 8. & RhStr_JH5+S1 & 18 & 83.33 & 1.64 & 16 & 1.35 & 562.32 & 603.022 \\
\hline
\end{tabular}

\subsection{Greenhouse experiments.}

The greenhouse (pot experiment) experiment was conducted to determine the effect of selected strains on the growth of Pisum sativum under salinity stress.

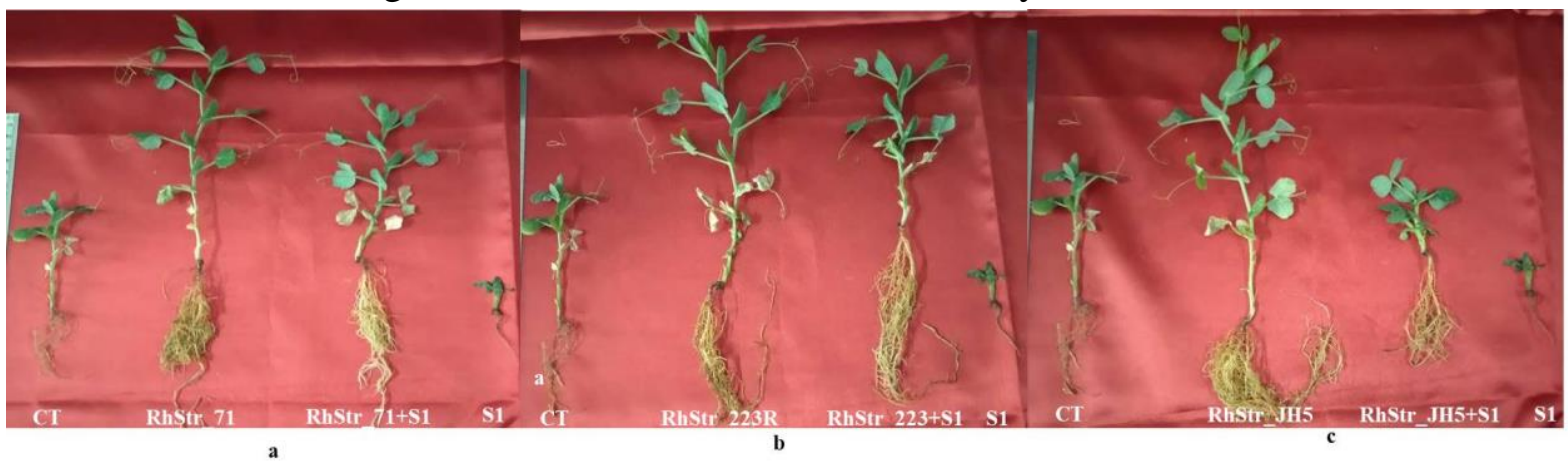

Figure 2. Effect of inoculated PGPRs on Pisum sativum under $1 \% \mathrm{NaCl}$ saline condition. (a) CT- control without bacterial inoculation, RhStr_71- PGPR strain (Bacillus subtilis), S1- 1\% salt stress, RhStr_71+S1PGPR $+\mathrm{NaCl}$ salt; (b) CT- control without bacterial inoculation, RhStr_223R- PGPR strain (Bacillus safensis), S1-1\% salt stress, RhStr_223R+S1-PGPR+NaCl salt; (c) CT- uninoculated; RhStr_JH5- PGPR (Bacillus cereus); S1-1\% salt stress, RhStr_JH5+S1-PGPR+NaCl salt.

Table 3. Effect of bacterial isolates on Pea plants after $30 \mathrm{DAS}$ at $1 \% \mathrm{NaCl}$ concentration compared to uninoculated (control). CT- Control without bacterial inoculation and salt; RhStr_71, RhStr_223, and RhStr_JH5 -

PGP isolates; S1- 1\% Salt stress, RhStr_71+S1, RhStr_223+S1, and RhStr_JH5+S1- bacterial isolates+salt inoculated plants with salinity stress.

\begin{tabular}{|c|c|c|c|c|c|c|c|}
\hline \multirow[t]{2}{*}{ S.No. } & \multirow{2}{*}{ Treatments } & \multicolumn{2}{|c|}{ Fresh weight (gm) } & \multicolumn{2}{|c|}{ Dry weight (gm) } & \multicolumn{2}{|c|}{ Length (cm) } \\
\hline & & Shoot & Root & Shoot & Root & Shoot & Root \\
\hline 1. & CT & $0.65 \pm 0.04^{\mathrm{a}}$ & $0.58 \pm 0.04^{\mathrm{a}}$ & $0.07 \pm 0.007^{\mathrm{a}}$ & $0.062 \pm 0.002^{\mathrm{a}}$ & $9.98 \pm 0.27^{\mathrm{a}}$ & $7.33 \pm 0.88^{\mathrm{a}}$ \\
\hline 2. & RhStr_71 & $1.22 \pm 0.14^{\mathrm{b}}$ & $1.27 \pm 0.07^{\mathrm{b}}$ & $0.15 \pm 0.004^{\mathrm{b}}$ & $0.16 \pm 0.01^{\mathrm{b}}$ & $14.73 \pm 0.37^{\mathrm{b}}$ & $17.41 \pm 0.82^{\mathrm{b}}$ \\
\hline 3. & RhStr_223R & $0.94 \pm 0.11^{\mathrm{abc}}$ & $0.89 \pm 0.06^{\mathrm{ac}}$ & $0.08 \pm 0.002^{\mathrm{a}}$ & $0.07 \pm 0.005^{\mathrm{a}}$ & $11.51 \pm 0.36^{\text {ac }}$ & $12.41 \pm 0.96^{\mathrm{c}}$ \\
\hline 4. & RhStr_JH5 & $0.89 \pm 0.03^{\mathrm{abc}}$ & $0.65 \pm 0.05^{\text {ad }}$ & $0.07 \pm 0.003^{\mathrm{ac}}$ & $0.061 \pm 0.002^{\mathrm{a}}$ & $10.70 \pm 0.81^{\text {acd }}$ & $10 \pm 0.58^{\mathrm{ac}}$ \\
\hline 5. & $\mathrm{~S} 1$ & $0.36 \pm 0.05^{\text {ad }}$ & $0.27 \pm 0.09^{\mathrm{e}}$ & $0.04 \pm 0.005^{\mathrm{d}}$ & $0.04 \pm 0.002^{\mathrm{a}}$ & $4.41 \pm 0.66^{\mathrm{e}}$ & $4.41 \pm 0.37^{\text {ae }}$ \\
\hline 6. & RhStr_ $71+\mathrm{S} 1$ & $0.88 \pm 0.06^{\mathrm{abc}}$ & $0.92 \pm 0.05^{\mathrm{cd}}$ & $0.08 \pm 0.003^{\mathrm{ac}}$ & $0.11 \pm 0.009^{c}$ & $11.10 \pm 0.49^{\mathrm{acd}}$ & $13.15 \pm 1.16^{c}$ \\
\hline 7. & RhStr_223R+S1 & $0.71 \pm 0.08^{\text {acd }}$ & $0.47 \pm 0.05^{\text {ad }}$ & $0.05 \pm 0.003^{\text {cd }}$ & $0.07 \pm 0.002^{\mathrm{a}}$ & $8.67 \pm 0.33^{\text {ad }}$ & $8.33 \pm 1.45^{\text {ac }}$ \\
\hline 8. & $\mathrm{RhStr} \_\mathrm{JH} 5+\mathrm{S} 1$ & $0.48 \pm 0.07^{\text {ad }}$ & $0.36 \pm 0.06^{\text {ae }}$ & $0.05 \pm 0.003^{\mathrm{d}}$ & $0.05 \pm 0.007^{\mathrm{a}}$ & $7.47 \pm 0.29^{f}$ & $7.15 \pm 0.46^{\mathrm{a}}$ \\
\hline
\end{tabular}


Pisum sativum L. fresh weight, dry weight, and Length on root and shoot were evaluated in salt stress's appearance and non-appearance. Results showed that $1 \% \mathrm{NaCl}$ had an adverse effect on plant growth parameters, thereby reducing the fresh weight $(\mathrm{FW})$ and dry weight (DW) and shoot (SL), and root length (RL) of Pea plant (Figure 2 and Table 2). Among these isolates, RhStr_71 strain showed a significant difference in plant growth characteristics (Table 2) compared to non-inoculation as a control. Thus we concluded that salinity stress could adversely affect plant growth, but on inoculation, these isolates may reduce the inhibitory effect of the salt.

\subsection{Biochemical parameters analysis.}

\subsubsection{Total sugar, reducing sugar and protein.}

Analysis of total sugar, reducing sugar, and protein content showed that $\mathrm{NaCl}$ salt's presence causes a reduction in the total sugar, reducing sugar, and protein contents in Pisum sativum. While on bacterial inoculation, they were considerably higher compared to stressed control, which led to the improvement of plant growth and biomass production.

\subsubsection{Photosynthetic pigments (chlorophyll $\mathrm{a}, \mathrm{chl} \mathrm{b}$ total chl and carotenoids).}

When the plants are grown with PGP bacteria under saline conditions, the plants have the highest chlorophylls, carotenoid contents, and healthy leaves compared to $\mathrm{NaCl}$ induced plants. The chlorophyll a, chlorophyll $\mathrm{b}$, total chlorophyll and carotenoids contents were 0.35 $\mathrm{mg} \mathrm{g}^{-1} \mathrm{FW}, 0.27 \mathrm{mg} \mathrm{g}^{-1} \mathrm{FW}, 0.45 \mathrm{mg} \mathrm{g}^{-1} \mathrm{FW}$ and $0.63 \mathrm{mg} \mathrm{g}^{-1} \mathrm{FW}$ (Figure 3b) respectively in plants with PGP bacteria under salt-stress conditions.

\subsubsection{Flavonoids, phenol, and proline.}

The application of these PGP bacteria resulted in increasing the flavonoids and phenolic contents in Pisum sativum. Among the 3 isolates, RhStr_71significantly increases the phenolic content. The data conferring in Figure 3(c) also shows that salinity stress significantly induced the proline biosynthesis. The high level of proline accumulation leads to the induction of osmotic stress, thereby causing damage to the plant membrane. However, a significant increase was observed when the plants were exposed to $\mathrm{NaCl}$ stress. Therefore, bacterial inoculation with RhStr_71, RhStr_223, and RhStr_JH5 was much more effective in alleviating salinity's adverse effect in Pisum sativum.

\subsection{Antioxidants assay.}

To overcome the deleterious effect of ROS, the plant cells have developed the antioxidants machinery. The antioxidants enzymatic activities were evaluated in un-inoculated and inoculated plants under salinity stress treatment. The antioxidants enzymatic activities of SOD, CAT, POX, and APX in Pea plants were lower in un-inoculated and salt inoculated plants than PGPR inoculated. Application of $\mathrm{NaCl}$ (salt) stress leads to induction of antioxidant enzymes irrespective of PGP bacterial inoculation. However, antioxidant activity was higher when treated with PGPR isolates (Figure 4) than in un-inoculated plants. The plant growthpromoting bacteria inoculation of the Pea plant had significantly decreased the lipid peroxidation (LPX) level in the shoot $(1 \% \mathrm{NaCl})$, which proposes that the membrane structures in Pea plant tissues are significantly less prone to the factors which are responsible for peroxidation. 

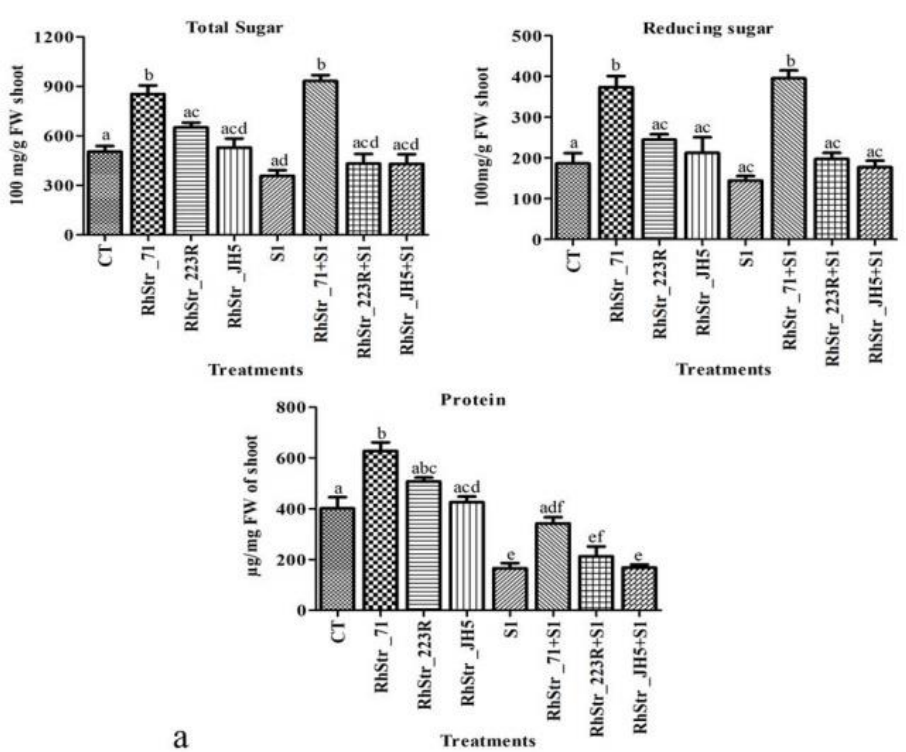

a
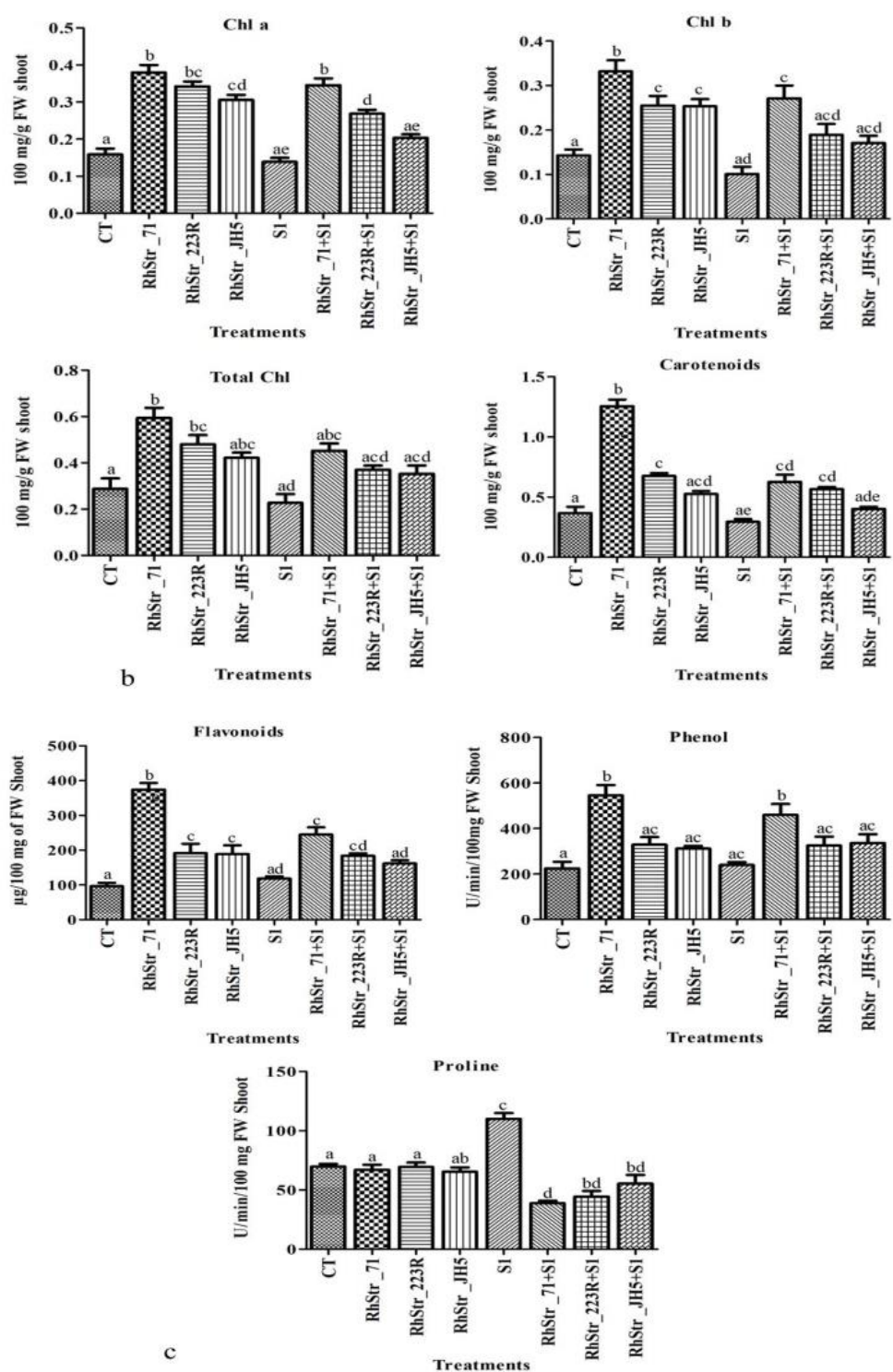

Figure 3. Effect of PGP bacteria on (a) total sugar, reducing sugar and protein; (b) chlorophyll a, chlorophyll b, total chlorophyll, and carotenoids; (c) flavonoids, phenol, and proline content in Pea shoot under salt-stress conditions. Similar letters represent the non-significant among the sample. Error bars represent \pm standard error mean. CT-control; RhStr_71, RhStr_223, and RhStr_JH5 - PGP isolates; S1- 1\% Salt stress. 


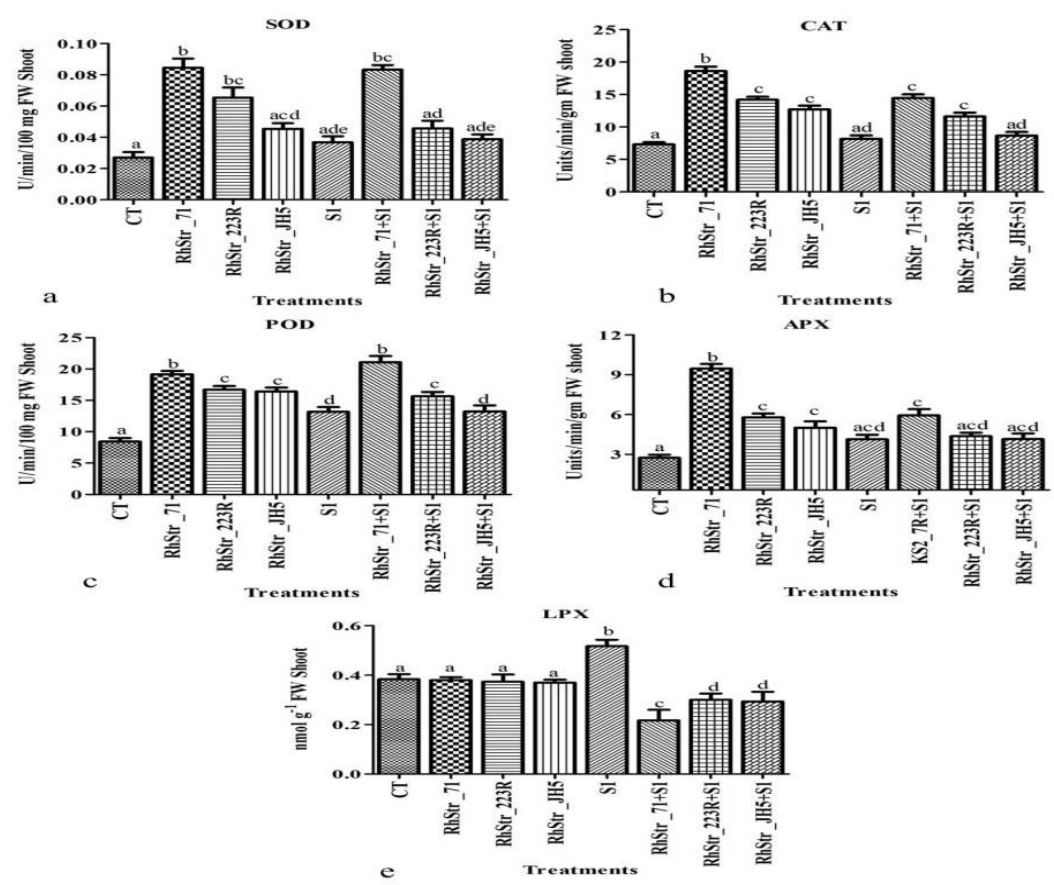

Figure 4. Effect of beneficial microbes and salt on antioxidants enzymes of Pisum sativum plants. (a) Superoxide Dismutase (SOD) activity, (b) Catalase (CAT) activity, (c) Peroxidase (POD) activity, (d) Ascorbate Peroxidase (APX) activity, and (e) Lipid peroxidase (LPX) activity. Data are presented as a mean of 3 replicates. Different letters denote significance amongst treatment groups according to Tukey's test $(\mathrm{P} \leq 0.05)$. Error bars represent \pm standard error mean. CT-control; RhStr_71, RhStr_223, and RhStr_JH5 - PGP strains; S1- $1 \%$ salt stress.

\subsection{Discussion.}

Our results discovered that these PGP isolates did not decrease their bacterial count at $2 \% \mathrm{NaCl}(\mathrm{w} / \mathrm{v})$, but the bacterial count decreased by increasing the $\mathrm{NaCl}$ concentration. Thus, it shows the adverse effect of $\mathrm{NaCl}$ salt on bacterial cell counts. As described in this work, the inoculation of Bacillus sp. is found to increase the entire seedling, morphological, and biochemical parameters under $\mathrm{NaCl}$ stress conditions. These bacterial isolates' beneficial effect in promoting plant growth is due to their PGP traits like IAA, P-solubilization, ammonia, and siderophore production. Similar PGP activities were also reported by [45].

Salinity has an adverse inhibited effect on seed germination due to osmotic/ionic effects [46], resulting in the disturbed water uptake, thereby causing the [47]. The unfavorable effect of $\mathrm{NaCl}$ on seed germination and its growth parameters has also been committed by many other scientists [47, 48]. By observing our study, salinity has a considerable effect on seedlings, their germination, germination time and rate, seedling vigor index, fresh and dry biomass, root and shoot lengths, [49], etc. and so the hypocotyl and plant shoot length is noted both in the bacterial inoculated and un-inoculated treatments. This work may have actual consequences in the agriculture sector as these factors are responsible for determining plant productivity [50]. It has also been reported by $[51,52]$ that salinity has more adverse effects on shoot compared to roots [53]. Many research also validated that PGPR inoculation on pepper seeds exhibited higher morphological parameters such as plant height, greater root length, larger leaf size, and an increase in dry matter in saline soils [54].

These bacterial inoculations can also increase the chlorophyll contents in the host (Pea) plant. A similar result has also been informed by [55] and thereby confirming the presented 
results in this work. Enhanced chlorophylls content in the PGPR inoculated plant also led to increased synthesis of photo-assimilates [56], as well as changes in Nitrogen, Phosphorous, and Potassium uptake [57].

To understand their inhibitory effect on plant growth, we further perform several biochemical assays such as total sugar, reducing sugar, protein, chlorophylls, carotenoid, phenol, and flavonoids content. The antioxidants enzymatic activity was also performed to analyze the level of proline, SOD, CAT, POD, APX, and LPX. Each of the assays considered different mechanisms to respond towards salinity stress. The salt stress may lead to oxidative stress, thereby causing photo-oxidative damage, which leads to photo-inhibition in leaves [58].

The increase in phenol and flavonoid contents under $\mathrm{NaCl}$ stress revealed its protective role towards plants by activating the cell signaling process, thereby up-regulating the phenylpropanoid pathway and increasing the ROS scavenging enzymes. The increased flavonoid level in plants also reduces the harmful hydroxyl radicals in plant cells generated due to abiotic (saline) stress. The increased proline concentrations under $\mathrm{NaCl}$ stress have also been reported in many plant species, such as tomatoes [59], B. juncea [60], and are considered as a primary defense response linked with the changing osmotic pressure in the plant cells [61]. Inoculation of Bacillus isolates (RhStr_71, RhStr_223, and RhStr_JH5) revealed a decreased proline level, in-plant shoot growing under saline condition. Lowering of proline content in Pea plants by PGP bacterial inoculation has also been reported by [56]. In order to curb the oxidative damages, plants had developed antioxidant mechanisms involving enzymes such as SOD, CAT POD, APX, and LPX [62, 63]. Inoculation of bacterial strains had a similarly significant effect on antioxidant machinery, thereby protecting the plants from oxidative burst $[64,65]$. This is the first study to examine the effect of these isolates on plant-microbe interactions under salinity stress conditions. The hypothesis tested during this study estate that RhStr_71 (Bacillus subtilis), RhStr_223R (Bacillus safensis), and RhStr_JH5 (Bacillus cereus) supplementation will boost Pea plant growth, thereby correcting ion imbalance, conquering the oxidative stress level, augmenting osmoprotectants, and antioxidants activities. These obtainable results will play an indispensable role in attenuating salinity stress.

\section{Conclusions}

Inoculation of these PGP Bacillus isolates under abiotic (salt) stress conditions leads to increased plant growth parameters with a simultaneous increase in antioxidants enzymes, thereby decreasing the oxidative stress. The work further indicated the potential activity of PGP bacteria for Pea growth promotion under $\mathrm{NaCl}$ stress. Therefore we concluded that PGP bacterial isolates such as Bacillus subtilis $\mathrm{RhStr}$ _71, Bacillus safensis $\mathrm{RhStr}$-223, and Bacillus cereus RhStr_JH5 supplementation will boost the Pea plant growth by correcting ion imbalance, suppressing oxidative stress level, maximizing osmoprotectants and antioxidants activities. These obtainable results play an essential role in attenuating salinity stress in agriculture. The knowledge gained from this study will help to boost the salt stress control management strategies for essential crops in difficult or stressed environments.

\section{Funding}

This research was funded by the Department of Science and Technology, New Delhi, DST INSPIRE-IF160803 and Uttar Pradesh Council of Science and Technology, Lucknow, UPCST/D-514 


\section{Acknowledgments}

The authors are grateful to Integral University for providing MCN number IU/R\&D/2021MCN0001043.

\section{Conflicts of Interest}

The authors declare no conflict of interest.

\section{References}

1. Farahmand, N.; Sadeghi, V. Estimating Soil Salinity in the Dried Lake Bed of Urmia Lake Using Optical Sentinel-2 Images and Nonlinear Regression Models. Journal of the Indian Society of Remote Sensing 2020, 48, 675-687, https://doi.org/10.1007/s12524-019-01100-8.

2. Ansari, F.A.; Ahmad, I. Plant growth promoting attributes and alleviation of salinity stress to wheat by biofilm forming Brevibacterium sp. FAB3 isolated from rhizospheric soil. Saudi J. Biol. Sci. 2018, https://doi.org/10.1016/j.sjbs.2018.08.003.

3. Srivastava, P.; Wu, Q.-S.; Giri, B. Salinity: an overview. In Microorganisms in Saline Environments: Strategies and Functions, Springer: 2019; 3-18, https://doi.org/10.1007/978-3-030-18975-4_1.

4. Sijilmassi, B.; Filali-Maltouf, A.; Fahde, S.; Ennahli, Y.; Boughribil, S.; Kumar, S.; Amri, A. In-Vitro Plant Growth Promotion of Rhizobium Strains Isolated from Lentil Root Nodules under Abiotic Stresses. Agronomy 2020, 10(7), 1006, https://doi.org/10.3390/agronomy10071006.

5. Singh, S.; Kumar, V.; Sidhu, G.K.; Datta, S.; Dhanjal, D.S.; Koul, B.; Janeja, H.S.; Singh, J. Plant growth promoting rhizobacteria from heavy metal contaminated soil promote growth attributes of Pisum sativum L. Biocatalysis and Agricultural Biotechnology 2019, 17, 665-671, https://doi.org/10.1016/j.bcab.2019.01.035.

6. Gupta, A. Effect of PGPR isolates on Plant growth promotion in relation to salinity stress. Bull Env Pharmacol Life Sci 2019, 8, 18-26.

7. Munns, R.; Tester, M. Mechanisms of Salinity Tolerance. Annu. Rev. Plant Biol. 2008, 59, 651-681, https://doi.org/10.1146/annurev.arplant.59.032607.092911.

8. Iqbal, N.; Hussain, S.; Raza, M. A.; Yang, C. Q.; Safdar, M. E.; Brestic, M.; Liu, J. Drought tolerance of soybean (Glycine max L. Merr.) by improved photosynthetic characteristics and an efficient antioxidant enzyme activities under a split-root system. Frontiers in physiology 2019, 10, 786. https://doi.org/10.3389/fphys.2019.00786.

9. Parihar, P.; Singh, S.; Singh, R.; Singh, V.P.; Prasad, S.M. Effect of salinity stress on plants and its tolerance strategies: a review. Environmental Science and Pollution Research 2015, 22, 4056-4075, https://doi.org/10.1007/s11356-014-3739-1.

10. Panuccio, M.R.; Jacobsen, S.E.; Akhtar, S.S.; Muscolo, A. Effect of saline water on seed germination and early seedling growth of the halophyte quinoa. AoB PLANTS 2014, 6, https://doi.org/10.1093/aobpla/plu047.

11. Kim, K.; Jang, Y.-J.; Lee, S.-M.; Oh, B.-T.; Chae, J.-C.; Lee, K.-J. Alleviation of salt stress by Enterobacter sp. EJ01 in tomato and Arabidopsis is accompanied by up-regulation of conserved salinity responsive factors in plants. Mol. Cells 2014, 37, 109, https://doi.org/10.14348/molcells.2014.2239.

12. Parida, A.K.; Das, A.B. Salt tolerance and salinity effects on plants: a review. Ecotoxicol. Environ. Saf. 2005, 60, 324-349, https://doi.org/10.1016/j.ecoenv.2004.06.010.

13. He, Y.; Wu, Z.; Wang, W.; Ye, B.-C.; Zhang, F.; Liu, X. Different Responses of Capsicum annuum L. Root and Shoot to Salt Stress with Pseudomonas putida Rs-198 Inoculation. J. Plant Growth Regul. 2019, 38, 799811, https://doi.org/10.1007/s00344-018-9891-y.

14. Kumar, K.; Amaresan, N.; Madhuri, K. Alleviation of the adverse effect of salinity stress by inoculation of plant growth promoting rhizobacteria isolated from hot humid tropical climate. Ecol. Eng. 2017, 102, 361366, https://doi.org/10.1016/j.ecoleng.2017.02.023.

15. Singh, S.P.; Gaur, R. Endophytic Streptomyces spp. underscore induction of defense regulatory genes and confers resistance against Sclerotium rolfsii in chickpea. Biol. Control 2017, 104, 44-56, https://doi.org/10.1016/j.biocontrol.2016.10.011.

16. Rady, M.M.; Talaat, N.B.; Abdelhamid, M.T.; Shawky, B.T.; Desoky, E.-S.M. Maize (Zea mays L.) grains extract mitigates the deleterious effects of salt stress on common bean (Phaseolus vulgaris L.) growth and 
physiology. The Journal of Horticultural Science and Biotechnology 2019, 94, 777-789, https://doi.org/10.1080/14620316.2019.1626773.

17. Wani, S.H.; Kumar, V.; Khare, T.; Guddimalli, R.; Parveda, M.; Solymosi, K.; Suprasanna, P.; Kavi Kishor, P.B. Engineering salinity tolerance in plants: progress and prospects. Planta 2020, 251, 76, https://doi.org/10.1007/s00425-020-03366-6.

18. Li, Y.; Fan, Y.; Ma, Y.; Zhang, Z.; Yue, H.; Wang, L.; Li, J.; Jiao, Y. Effects of Exogenous $\gamma$-Aminobutyric Acid (GABA) on Photosynthesis and Antioxidant System in Pepper (Capsicum annuum L.) Seedlings Under Low Light Stress. J. Plant Growth Regul. 2017, 36, 436-449, https://doi.org/10.1007/s00344-016-9652-8.

19. Gupta, B.; Huang, B. Mechanism of Salinity Tolerance in Plants: Physiological, Biochemical, and Molecular Characterization. International Journal of Genomics 2014, 2014, 701596, https://doi.org/10.1155/2014/701596.

20. Wang, H.; Tang, X.; Wang, H.; Shao, H.-B. Proline accumulation and metabolism-related genes expression profiles in Kosteletzkya virginica seedlings under salt stress. Frontiers in Plant Science 2015, 6, 792, https://doi.org/10.3389/fpls.2015.00792.

21. Desoky, E.-S.M.; Saad, A.M.; El-Saadony, M.T.; Merwad, A.-R.M.; Rady, M.M. Plant growth-promoting rhizobacteria: Potential improvement in antioxidant defense system and suppression of oxidative stress for alleviating salinity stress in Triticum aestivum (L.) plants. Biocatalysis and Agricultural Biotechnology 2020, 30, 101878, https://doi.org/10.1016/j.bcab.2020.101878.

22. Gupta, A.; Singh, S. K.; Singh, M. K.; Singh, V. K.; Modi, A.; Singh, P. K.; Kumar, A. Plant growthpromoting rhizobacteria and their functional role in salinity stress management. In Abatement of Environmental Pollutants 2020, 151-160, https://doi.org/10.1016/B978-0-12-818095-2.00007-2.

23. Al-Barakah, F.N.I.; Sohaib, M. Evaluating the germination response of Chenopodium quinoa seeds to bacterial inoculation under different germination media and salinity conditions. Seed Science and Technology 2019, 47, 161-169, https://doi.org/10.15258/sst.2019.47.2.05.

24. Zhang, Y.; Li, T.; Liu, Y.; Li, X.; Zhang, C.; Feng, Z.; Peng, X.; Li, Z.; Qin, S.; Xing, K. Volatile Organic Compounds Produced by Pseudomonas chlororaphis subsp. aureofaciens SPS-41 as Biological Fumigants To Control Ceratocystis fimbriata in Postharvest Sweet Potatoes. J. Agric. Food Chem. 2019, 67, 3702-3710, https://doi.org/10.1021/acs.jafc.9b00289.

25. Gordon, S.A.; Weber, R.P. Colorimetric estimation of indoleacetic acid. Plant Physiol. 1951, 26, 192, https://doi.org/10.1104/pp.26.1.192.

26. King, E.J. The colorimetric determination of phosphorus. Biochem. J. 1932, 26, 292-297, https://doi.org/10.1042/bj0260292.

27. Goswami, D.; Dhandhukia, P.; Patel, P.; Thakker, J.N. Screening of PGPR from saline desert of Kutch: Growth promotion in Arachis hypogea by Bacillus licheniformis A2. Microbiol. Res. 2014, 169, 66-75, https://doi.org/10.1016/j.micres.2013.07.004.

28. Schwyn, B.; Neilands, J.B. Universal chemical assay for the detection and determination of siderophores. Anal. Biochem. 1987, 160, 47-56, https://doi.org/10.1016/0003-2697(87)90612-9.

29. Mahajan, S.G.; Nandre, V.S.; Salunkhe, R.C.; Shouche, Y.S.; Kulkarni, M.V. Chemotaxis and physiological adaptation of an indigenous abiotic stress tolerant plant growth promoting Pseudomonas stutzeri: Amelioration of salt stress to Cicer arietinum. Biocatalysis and Agricultural Biotechnology 2020, 27, 101652, https://doi.org/10.1016/j.bcab.2020.101652.

30. Ruan, S.; Xue, Q.; Tylkowska, K. Effect of priming on germination and health of rice (Oryza sativa L.) seeds. Seed Science and Technology 2002, 30, 451-458.

31. Soltani, E.; Ghaderi-Far, F.; Baskin, C.C.; Baskin, J.M. Problems with using mean germination time to calculate rate of seed germination. Aust. J. Bot. 2015, 63, 631-635, https://doi.org/10.1071/BT15133.

32. Dubois, M.; Gilles, K.; Hamilton, J.K.; Rebers, P.A.; Smith, F. A Colorimetric Method for the Determination of Sugars. Nature 1951, 168, 167-167, https://doi.org/10.1038/168167a0.

33. Nelson, N. A photometric adaptation of the Somogyi method for the determination of glucose. J. biol. Chem 1944, 153, 375-380, https://doi.org/10.1016/s0021-9258(18)71980-7.

34. Lowry, O.H.; Rosebrough, N.J.; Farr, A.L.; Randall, R.J. Protein measurement with the Folin phenol reagent. The Journal of biological chemistry 1951, 193, 265-275.

35. Arnon, D.I. Copper enzymes in isolated chloroplasts. Polyphenoloxidase in Beta vulgaris. Plant Physiol. 1949, 24, 1, https://doi.org/10.1104/pp.24.1.1.

36. Bates, L.S.; Waldren, R.P.; Teare, I.D. Rapid determination of free proline for water-stress studies. Plant Soil 1973, 39, 205-207, https://doi.org/10.1007/BF00018060. 
37. McDonald, S.; Prenzler, P.D.; Antolovich, M.; Robards, K. Phenolic content and antioxidant activity of olive extracts. Food Chem. 2001, 73, 73-84, https://doi.org/10.1016/S0308-8146(00)00288-0.

38. Chang, C.-C.; Yang, M.-H.; Wen, H.-M.; Chern, J.-C. Estimation of total flavonoid content in propolis by two complementary colorimetric methods. J. Food Drug Anal. 2002, 10, https://doi.org/10.38212/22246614.2748.

39. Giannopolitis, C.N.; Ries, S.K. Superoxide Dismutases. Plant Physiol. 1977, 59, 309, https://doi.org/10.1104/pp.59.2.309.

40. Kono, Y. Generation of superoxide radical during autoxidation of hydroxylamine and an assay for superoxide dismutase. Arch. Biochem. Biophys. 1978, 186, 189-195, https://doi.org/10.1016/0003-9861(78)90479-4.

41. Aebi, H. Catalase in vitro. In Methods Enzymol., Academic Press: 1984, 105, 121-126. https://doi.org/10.1016/S0076-6879(84)05016-3.

42. Chance, B.; Maehly, A.C. [136] Assay of catalases and peroxidases. In Methods Enzymol., Academic Press: 1955; Vol. 2, 764-775, https://doi.org/10.1016/S0076-6879(55)02300-8.

43. Chen, G.-X.; Asada, K. Inactivation of Ascorbate Peroxidase by Thiols Requires Hydrogen Peroxide. Plant Cell Physiol. 1992, 33, 117-123, https://doi.org/10.1093/oxfordjournals.pcp.a078229.

44. Ayala, A.; Muñoz, M.F.; Argüelles, S. Lipid Peroxidation: Production, Metabolism, and Signaling Mechanisms of Malondialdehyde and 4-Hydroxy-2-Nonenal. Oxid. Med. Cell. Longev. 2014, 2014, 360438, https://doi.org/10.1155/2014/360438.

45. Qin, S.; Feng, W.-W.; Wang, T.-T.; Ding, P.; Xing, K.; Jiang, J.-H. Plant growth-promoting effect and genomic analysis of the beneficial endophyte Streptomyces sp. KLBMP 5084 isolated from halophyte Limonium sinense. Plant Soil 2017, 416, 117-132, https://doi.org/10.1007/s11104-017-3192-2.

46. Nasri, N.; Saïdi, I.; Kaddour, R.; Lachaâl, M. Effect of salinity on germination, seedling growth and acid phosphatase activity in lettuce. American Journal of Plant Sciences 2015, 6, 57, https://doi.org/10.4236/ajps.2015.61007.

47. Bybordi, A. The influence of salt stress on seed germination, growth and yield of canola cultivars. Notulae Botanicae Horti Agrobotanici Cluj-Napoca 2010, 38, 128-133.

48. Ghorbannejad, H.; Amooaghaie, R. Differential Changes of Proline Content and Activities of Antioxidant Enzymes Results in Varied Salt-Tolerance in Canola Genotypes. Journal of Genetic Resources 2017, 3, 3646, https://doi.org/10.22080/jgr.2018.13281.1075.

49. Bal, H.B.; Nayak, L.; Das, S.; Adhya, T.K. Isolation of ACC deaminase producing PGPR from rice rhizosphere and evaluating their plant growth promoting activity under salt stress. Plant Soil 2013, 366, 93105, https://doi.org/10.1007/s11104-012-1402-5.

50. ShahrajabİAn, M.H.; Khoshkharam, M.; Wenlİ, S.; Cheng, Q. The effects of pretreatment factors on seed germination and seedling growth of anise (Pimpinella anisum L.). Middle East Journal of Science 2019, 5, 86-93, https://doi.org/10.23884/mejs.2019.5.1.09.

51. Munns, R. Comparative physiology of salt and water stress. Plant, Cell Environ. 2002, 25, 239-250, https://doi.org/10.1046/j.0016-8025.2001.00808.x.

52. Ramoliya, P.J.; Patel, H.M.; Joshi, J.B.; Pandey, A.N. Effect of Salinization of Soil on Growth and Nutrient Accumulation in Seedlings of Prosopis cineraria. J. Plant Nutr. 2006, 29, 283-303, https://doi.org/10.1080/01904160500476806.

53. Orhan, F. Alleviation of salt stress by halotolerant and halophilic plant growth-promoting bacteria in wheat (Triticum aestivum). Braz. J. Microbiol. 2016, 47, 621-627, https://doi.org/10.1016/j.bjm.2016.04.001.

54. Abdel Latef, A.A.H.; Chaoxing, H. Does Inoculation with Glomus mosseae Improve Salt Tolerance in Pepper Plants? J. Plant Growth Regul. 2014, 33, 644-653, https://doi.org/10.1007/s00344-014-9414-4.

55. Habib, S.H.; Kausar, H.; Saud, H.M. Plant Growth-Promoting Rhizobacteria Enhance Salinity Stress Tolerance in Okra through ROS-Scavenging Enzymes. BioMed Research International 2016, 2016, 6284547, https://doi.org/10.1155/2016/6284547.

56. Abd_Allah, E.F.; Alqarawi, A.A.; Hashem, A.; Radhakrishnan, R.; Al-Huqail, A.A.; Al-Otibi, F.O.N.; Malik, J.A.; Alharbi, R.I.; Egamberdieva, D. Endophytic bacterium Bacillus subtilis (BERA 71) improves salt tolerance in chickpea plants by regulating the plant defense mechanisms. Journal of Plant Interactions 2018, 13, 37-44, https://doi.org/10.1080/17429145.2017.1414321.

57. Dawwam, G.E.; Elbeltagy, A.; Emara, H.M.; Abbas, I.H.; Hassan, M.M. Beneficial effect of plant growth promoting bacteria isolated from the roots of potato plant. Annals of Agricultural Sciences 2013, 58, 195201, https://doi.org/10.1016/j.aoas.2013.07.007. 
58. Szymańska, S.; Dąbrowska, G.B.; Tyburski, J.; Niedojadło, K.; Piernik, A.; Hrynkiewicz, K. Boosting the Brassica napus L. tolerance to salinity by the halotolerant strain Pseudomonas stutzeri ISE12. Environ. Exp. Bot. 2019, 163, 55-68, https://doi.org/10.1016/j.envexpbot.2019.04.007.

59. Souri, M. K.; Tohidloo, G. Effectiveness of different methods of salicylic acid application on growth characteristics of tomato seedlings under salinity. Chemical and Biological Technologies in Agriculture 2019, 6(1), 1-7, https://doi.org/10.1186/s40538-019-0169-9.

60. Kumar, M.; Kumar, R.; Jain, V.; Jain, S. Differential behavior of the antioxidant system in response to salinity induced oxidative stress in salt-tolerant and salt-sensitive cultivars of Brassica juncea L. Biocatalysis and Agricultural Biotechnology 2018, 13, 12-19, https://doi.org/10.1016/j.bcab.2017.11.003.

61. de Freitas, P. A. F.; de Carvalho, H. H.; Costa, J. H.; de Souza Miranda, R.; da Cruz Saraiva, K. D.; de Oliveira, F. D. B.; Gomes-Filho, E. Salt acclimation in sorghum plants by exogenous proline: physiological and biochemical changes and regulation of proline metabolism. Plant cell reports 2019, 38(3), 403-416, https://doi.org/10.1007/s00299-019-02382-5.

62. Gill, S.S.; Tuteja, N. Reactive oxygen species and antioxidant machinery in abiotic stress tolerance in crop plants. Plant Physiol. Biochem. 2010, 48, 909-930, https://doi.org/10.1016/j.plaphy.2010.08.016.

63. Zhu, Y.; Luo, X.; Wei, M.; Khan, A.; Munsif, F.; Huang, T.; Shan, Z. Antioxidant Enzymatic Activity and Its Related Genes Expression in Cassava Leaves at Different Growth Stages Play Key Roles in Sustaining Yield and Drought Tolerance Under Moisture Stress. Journal of Plant Growth Regulation 2019, 1-14, https://doi.org/10.1007/s00344-019-10003-4.

64. Pan, J.; Peng, F.; Xue, X.; You, Q.; Zhang, W.; Wang, T.; Huang, C. The Growth Promotion of Two SaltTolerant Plant Groups with PGPR Inoculation: A Meta-Analysis. Sustainability 2019, 11, https://doi.org/10.3390/su11020378.

65. Zou, Y.N.; Wu, Q.S.; Kuča, K. Unravelling the role of arbuscular mycorrhizal fungi in mitigating the oxidative burst of plants under drought stress. Plant Biol. 2020, n/a, https://doi.org/10.1111/plb.13161 